\title{
KONSEP RUANG BELAJAR ADAPTATIF UNTUK ANAK SEKOLAH DASAR SEBAGAI RESPON TERHADAP PANDEMI
}

\author{
Febrione Putri Rakhmanty \\ Program Studi Arsitektur, Fakultas Teknik, Universitas Tunas Pembangunan \\ febrione.putri@lecture.utp.ac.id
}

\begin{abstract}
Abstrak
Setelah lebih dari satu tahun sejak model Pembelajaran Jarak Jauh (PJJ) mulai diterapkan demi pencegahan penyebaran Covid-19, kini mulai terdapat wacana untuk menerapkan model pembelajaran ini secara permanen. Wacana ini memicu pro kontra, salah satunya karena tidak semua rumah tinggal memiliki fasilitas yang memadai untuk melangsungkan model pembelajaran ini. Tulisan ini bertujuan untuk memberi masukan mengenai konsep ruang beajar yang adaptatif sebagai fasilitas untuk mendukung pelaksanaan proses PJJ secara maksimal untuk anak sekolah dasar usia 6-12 tahun. Metode penelitian yang akan digunakan adalah metode kualitatif dengan teknik penelitian content analysis (analisis isi), dimana penelitian akan menganalisa dokumen-dokumen sekunder baik dalam bentuk tulisan, rekaman suara, maupun rekaman visual, untuk mengetahui kecenderungan pola belajar siswa sekolah dasar sebelum dan pada saat penerapan PJJ, kualitas ruangan yang dibutuhkan untuk menunjang proses pembelajaran, serta hal lain terkait pandemi dan social distancing yang dianggap berhubungan dengan masalah utama, hingga akhirnya didapatkan konsep ruang belajar adaptatif sebagai respon terhadap pandemi yaitu (1)Pemberian bukaan untuk memasukkan cahaya dan pertukaran udara secara alami; (2)Peletakan ruang adaptatif di tengah rumah agar anak dapat sering berinteraksi dengan keluarga; (3)Mengatur arah orientasi belajar; (4)Memiliki akses langsung ke ruang terbuka dalam rumah; (5)Menggunakan material yang beragam.
\end{abstract}

Kata kunci: adaptatif, ruang, anak, belajar.

\begin{abstract}
After more than a year since the Distance Learning (PJJ) model was implemented to prevent the spread of Covid-19, there is now a discourse to implement this learning model permanently. This triggers many pros and cons, one of which is that not all residential houses have adequate facilities to carry out this learning model. This paper aims to provide input on the concept of an adaptive learning space as a facility to support the maximum implementation of the PJJ process for elementary school children aged 612 years. The research method that will be used is a qualitative method with content analysis research techniques (content analysis), where the research will analyze secondary documents in the form of writing, sound recordings, and visual recordings, to determine the tendency of elementary school students' learning patterns before and at the time of writing. the implementation of PJJ, the quality of the room needed to support the learning process, as well as other matters related to the pandemic and social distancing which were considered to be related to the main problem, until finally the concept of an adaptive study room was obtained as a response to the pandemic, namely (1) Providing openings to enter light and air exchange naturally (2) Laying an adaptive space in the middle of the house so that children can often interact with their families (3) setting the direction of learning orientation (4) Having direct access to open spaces in the house (5) Using a variety of materials.
\end{abstract}

Keywords: adaptive, space, child, learning 


\section{PENDAHULUAN}

\section{A. Latar Belakang}

Model pembelajaran jarak jauh sebenarnya sudah mulai digunakan sejak setidaknya dua dekade yang lalu sejak internet mulai dimanfaatkan dalam proses belajar-mengajar (Heinich et al, 2002, dalam Lestari, 2018)

Sejak pandemi Covid-19 mulai menyebar di akhir 2019, Pemerintah Indonesia telah banyak mengeluarkan kebijakan terkait pencegahan penyebaran Covid-19. Salah satunya adalah keputusan pemerintah untuk melaksakan Pembelajaran Jarak Jauh (selanjutnya disebut PJJ) di rumah demi memutus mata rantai penyebaran wabah (berdasarkan SE Mendikbud nomor 4 tahun 2020).

Hingga saat ini, terhitung sudah lebih dari satu tahun PJJ dilaksanakan. Walaupun pemerintah telah mulai mengizinkan pelaksanaan pembelajaran tatap muka secara terbatas, bukan berarti model PJJ tidak lagi digunakan. Sebaliknya, telah muncul wacana untuk menerapkan model pembelajaran ini secara permanen, ditambah kemungkinan munculnya pandemi lain di masa depan (Plump, 2021) yang mengharuskan pembelajaran tatap muka di sekolah harus ditiadakan kembali secara tiba-tiba.

Hal ini tentu saja memicu banyak kontra. dari masyarakat yang merasa pelaksanaan PJJ tidak bisa maksimal, khususnya pada anak usia sekolah dasar, dimana di satu sisi anak usia tersebut masih membutuhkan banyak waktu untuk bersosialisasi dan berkegiatan fisik dengan teman sebaya, sedangkan di sisi lain tetap diminta untuk mengejar studi secara mandiri, sementara tidak setiap rumah memiliki fasilitas yang dapat mendukung kebutuhankebutuhan tersebut. Hal ini sebenarnya bisa diatasi, salah satunya dengan menyediakan ruang adaptatif yang fungsinya dapat diubah menjadi ruang belajar apabila sewaktu-waktu diperlukan.

\section{B. Pertanyaan Penelitian}

Bagaimana membuat ruangan yang adaptatif untuk mendukung pelaksanaan proses PJJ secara maksimal untuk anak sekolah dasar usia 6-12 tahun.

\section{Tujuan}

Penelitian ini bertujuan untuk memberi masukan mengenai konsep ruang belajar yang adaptatif untuk mendukung pelaksanaan proses PJJ secara maksimal untuk anak sekolah dasar usia 6-12 tahun.

\section{METODE PENELITIAN}

Penelitian ini merupakan gabungan dari dua tipe penelitian yaitu basic research dan instrumental research. Hasil dari penelitian ini diharapkan dapat berguna untuk pengembangan teori baru mengenai konsep rumah tinggal terutama ruang belajar untuk anak, yang dapat merespon perubahan perilaku penghuninya ketika terjadi situasi tidak terduga di masa depan seperti pandemi. Berdasarkan pertanyaan penelitian yang akan dipecahkan dalam penelitian ini maka metode penelitian yang akan digunakan adalah metode kualitatif dengan 
teknik penelitian content analysis (analisis isi), dimana penelitian akan menganalisa dokumendokumen sekunder baik dalam bentuk tulisan, rekaman suara, maupun rekaman visual, untuk mengetahui kecenderungan pola belajar siswa sekolah dasar sebelum dan pada saat penerapan PJJ, kualitas ruangan yang dibutuhkan untuk menunjang proses pembelajaran, serta hal lain terkait pandemi dan social distancing yang dianggap berhubungan dengan masalah utama.

Penelitian Kualitatif memandang objek sebagai sesuatu yang dinamis, hasil konstruksi pemikiran dan interprestasi terhadap gejala yang diamati, serta utuh (holistic) karena setiap aspek dari objek itu mempunyai satu kesatuan yang tidak dapat dipisahkan (Sugiyono, 2014).

\section{TINJAUAN PUSTAKA}

\section{A. Karakteristik dan Kebutuhan Anak Sekolah}

\section{Dasar Usia 5-12 Tahun}

Terdapat empat faktor yang mempengaruhi perkembangan kognitif anak, yaitu:

1) Lingkungan fisik, artinya perlu adanya interaksi dengan dunia luar yang merupakan sumber pengetahuan baru dan dapat menambah pengalaman yang telah dimiliki sebelumnya;

2) Kematangan, artinya membuka kemungkinan untuk dapat berkembang agar tidak membatasi prestasi kognitif

3) Pengaruh sosial, termasuk penanaman bahasa dan pendidikan tentang pentingnya lingkungan sosial;

4) Equilibrasi, atau proses pengaturan diri yaitu bagaimana mengatur interaksi spesifik dari individu dengan lingkungan maupun pengalaman fisik, pengalaman sosial, dan perkembangan jasmani .

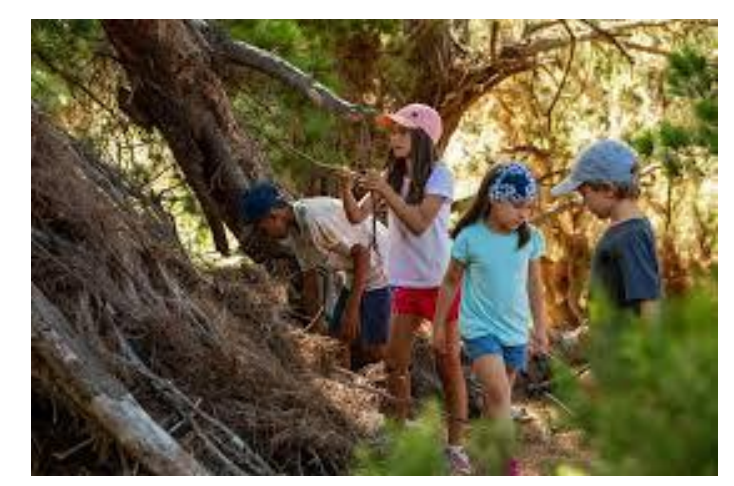

Gambar 1 Anak-anak bermain di luar sebagai bagian dari interaksi dengan lingkungan fisik yang berguna untuk perkembangan kognitifnya.

Sumber: www.buff.com (https://bit.ly/35Siuel)

Sementara itu, melihat dari kebutuhan belajarnya, ada beberapa karakteristik anak yang harus dipahami, yaitu:

1) Senang bermain. Sebisa mungkin aktivitas sehari-sehari yang dilakukan, termasuk belajar, tetap mengandung unsur permainan;

2) Senang bergerak. Durasi anak-anak bisa duduk tenang hanya sekitar 30 menit, untuk itu diperlukan cara belajar yang memungkinkan anak untuk berpindah atau bergerak;

3) Senang bekerja dalam kelompok. Dari bekerja dalam kelompok secara tidak langsung anak-anak belajar aspek-aspek yang penting dalam proses sosialisasi;

4) Senang merasakan atau melakukan dan memperagakan sesuatu secara langsung. Ditinjau dari teori perkembangan kognitif. Bagi anak, penjelasan tentang materi pelajaran akan lebih dipahami jika anak melaksanakan sendiri. 


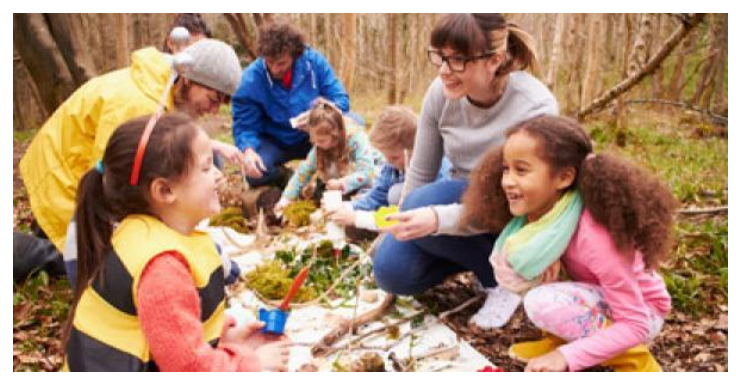

Gambar 2 Anak-anak berkegiatan dalam kelompok

Sumber: www.naey.org (https://bit.ly/2Sxnge8)

Menurut Havighurst (dalam Ameliasari, 2019) tugas perkembangan anak usia SD adalah sebagai berikut:

1) Menguasai keterampilan fisik yang diperlukan dalam permainan dan aktivitas fisik,

2) Membangun hidup sehat mengenai diri sendiri dan lingkungan.

3) Belajar bergaul dan bekerja antar teman dalam kelompok sebaya,

4) Belajar menjalankan peranan sosial sesuai dengan jenis kelamin

5) Mengembangkan keterampilan dasar dalam membaca, menulis, dan berhitung. agar nantinya diharapkan mampu berpartisipasi dalam masyarakat.

6) Mengembangkan konsep-konsep hidup yang perlu dalam kehidupan.

7) Mengembangkan kata hati, moral, dan nilainilai sebagai pedoman perilaku.

8) Mencapai kemandirian pribadi.

\section{B. Kriteria Ruang Belajar Anak}

Ruang tempat kita berada setiap hari seharusnya didesain menurut pengguna dan kebutuhannya. Fungsi arsitek adalah untuk membuat sebuah ruangan yang fungsional, dengan lingkungan yang aman dan nyaman, serta selaras dengan sekitarnya.

Terdapat beberapa aspek ruangan yang berpengaruh secara relevan ke proses pembelajaran anak. Hal-hal yang harus diperhatikan seperti (Skorobogatov, 2016) :

- Pencahayaan - bagaimana mood atau suasana yang ingin dicapai

- Visibilitas - apakah siswa dapat mendengar suara guru atau tutornya

- Material dan warna - diperlukan untuk memberikan suasana tertentu pada ruangan

- Orientasi - Dimana tempat yang tepat untuk menampilkan gambar atau paparan

- Ruang terbuka - terkoneksi dengan alam untuk memberikan rasa nyaman dan keinginan untuk tinggal lebih lama

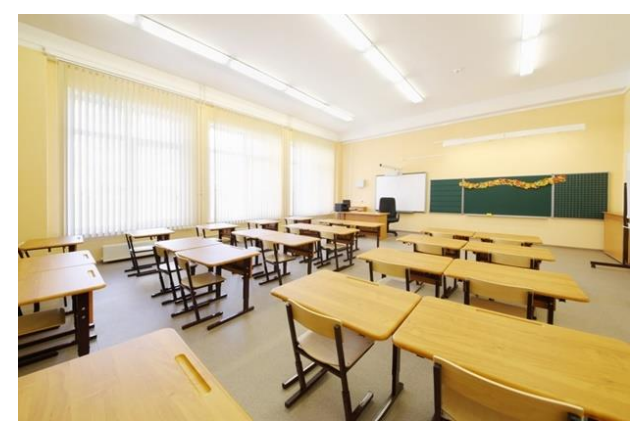

Gambar 3 Tipikal layout ruang kelas yang umum ditemukan di sekolah-sekolah Sumber: Laboratory of Style ( https://bit.ly/3qvThzW)

\section{Pro dan Kontra Proses Pembelajaran Jarak Jauh}

Berdasarkan survey yang dilakukan oleh Komisi Perlindungan Anak Indonesia di 20 provinsi di Indonesia pada tahun 2020 ditemukan bahwa $73,2 \%$ siswa berpendapat bahwa PJJ membuat stress yang diakibatkan oleh banyaknya tugas yang diberikan, tidak adanya interaksi langsung selama proses belajar, 
kurang bisa fokus, dan kurang istirahat (Harsono, 2020). Hal ini menyebabkan banyaknya kasus-kasus kesehatan mental yang kemudian dialami oleh siswa yang melaksanakan PJJ (Hasil survey KPAI, 2021) .

Kelas daring dirasa menyulitkan dalam penyesuaian karena tidak pernah ada simulasi yang dilakukan sebelumnya. Beberapa siswa mengatakan bahwa sebelumnya pelajaran di kelas biasa (pertemuan tatap muka langsung di sekolah) juga sulit, tapi adanya teman-teman di sekolah membuat kesulitan tersebut terasa lebih mudah dihadapi dan tidak terlalu membuat stress, suatu hal yang sulit untuk dipenuhi ketika melaksanakan PJJ, dimana siswa terjebak sendirian dengan tugas-tugasnya. Walaupun begitu ada pula siswa yang merasa bahwa PJJ adalah alternatif model pembelajaran yang dapat membuat mereka lebih fokus dengan studinya.

\section{KPAI: Banyak siswa stres hingga putus sekolah selama ikuti PJJ daring}

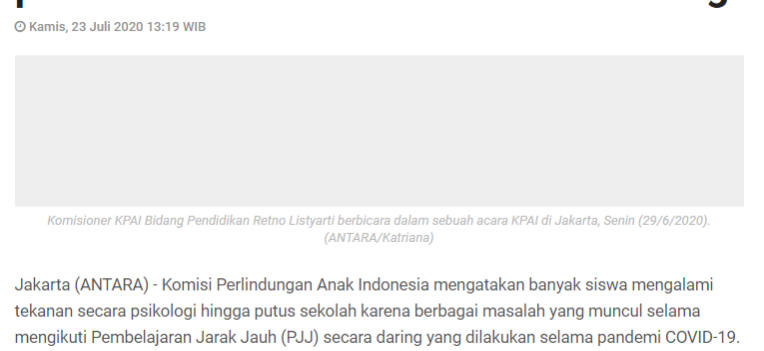

Gambar 4 Berita mengenai efek Pembelajaran Online terhadap siswa Sumber: Antara News (https://bit.ly/2S8FrGG)

\section{Covid-19: 'Stres, mudah marah, hingga dugaan bunuh diri', persoalan mental murid selama sekolah dari rumah}

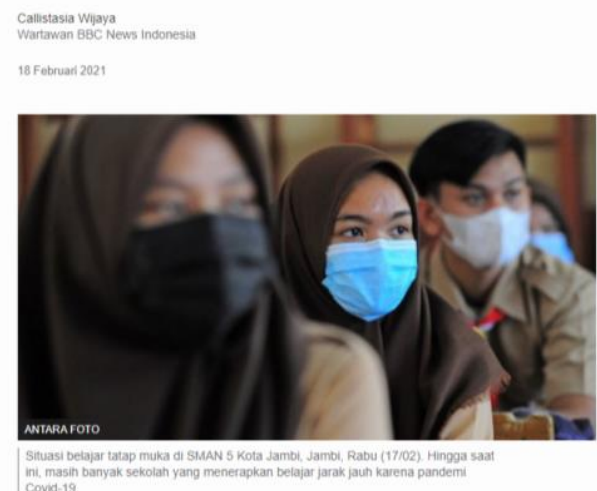

Gambar 5 Berita mengenai efek Pembelajaran Online terhadap siswa Sumber: BBC Indonesia (https://bbc.in/3wJKQDo)

\section{Ventilasi Ruangan untuk Mencegah Penyebaran Covid-19}

Terdapat beberapa tindakan preventif yang sebaiknya dilakukan demi mencegah penyebaran virus, seperti cuci tangan, memakai masker, dan melakukan social distancing. Menurut para peneliti, penggunaan ventilasi udara indoor yang layang seharusnya juga menjadi salah satu tindakan preventif dimana sebaiknya sirkulasi udara di sebuah ruangan dapat berganti setidaknya empat sampai 6 kali dalam satu jam untuk membuang partikelpartikel virus yang kemungkinan ada (McCabe, 2020).

Mengingat selama pandemi Covid-19 ini pemerintah menyarankan masyarakat untuk di rumah saja, yang juga berlaku untuk model Pembelajaran Jarak Jauh yang disarankan untuk dilaksanakan di rumah masing-masing siswa, maka pemberian ventilasi yang baik tentu sangat diperlukan.

Beberapa hal yang perlu diperhatikan untuk 
meningkatkan kualitas udara di rumah (Center for Disease Control and Prevention, 2021):

- Meningkatkan penggunaan udara dari luar dengan membuka jendela dan pintu jika cuaca memungkinkan

- Menggunakan kipas angina untuk meningkatkan efektivitas jendela yang terbuka

- Memastikan setiap ruangan memiliki sistem ventilasi yang memungkinkan pertukaran udara dengan lancar

- Menggunakan High Efficientsy Particulate Air (HEPA) flter portabel untuk menyaring udara

- Memastikan mesin penyaring udara berfungsi baik dan sesuai dengan kebutuhan ruang

- Memastikan exhaust fan berfungsi dengan baik

- Menggunakan Ultraviolet Germical Irradiation (UVGI) sebagai tindakan tambahan untuk mematikan virus

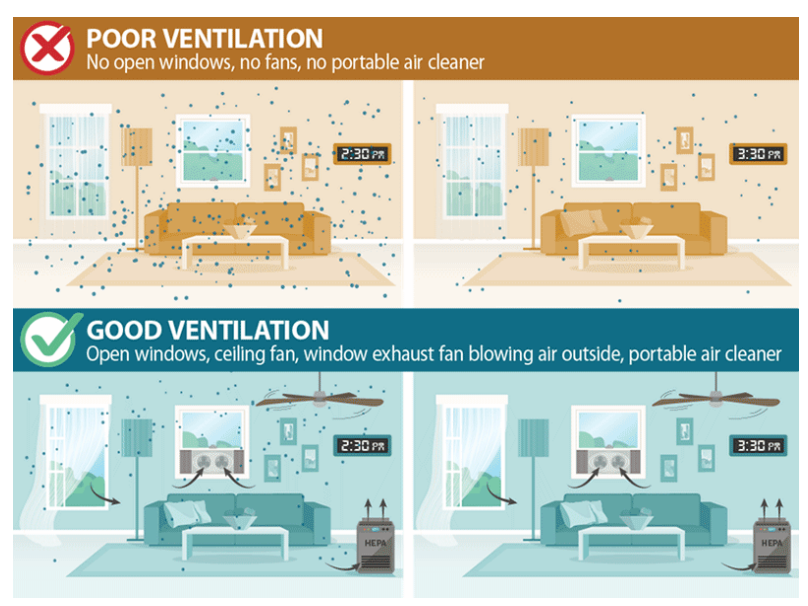

Gambar 6 Contoh ventilasi ruangan yang baik dan yang buruk

Sumber: Centers for Disease Control and Prevention (https://bit.ly/3jhOmAN)

Tindakan-tindakan preventif tersebut dapat dilakukan dengan sedikit biaya atau bahkan tanpa biaya sama sekali, seperti penggunaan kipas angin dan membuka jendela dan pintu. Untuk instalasi-instalasi lain seperti HEPA Filter dan UVGI diperlukan biaya mulai dari US\$ 500 hingga US\$ 2500.

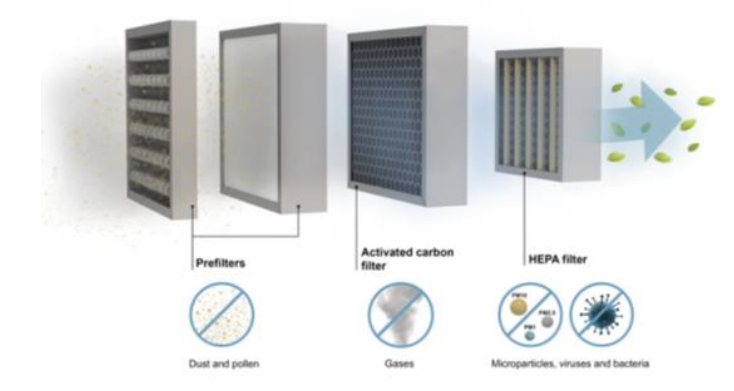

Gambar 7 Ilustrasi bagaimana HEPA Filter bekerja Sumber: Airtecnics (https://bit.ly/3diUSmW)

\section{USULAN KONSEP RUANG BELAJAR ADAPTATIF UNTUK ANAK SEKOLAH DASAR}

Kivilia (2015, dalam Skorobogatov, 2016) menyebutkan ruang belajar tidak memiliki ruang atau bentuk yang spesifik. “Keberagaman" adalah kata kunci utama ketika mendesain ruang belajar untuk anak, dimana ruang tersebut sebaiknya memberikan sebanyak mungkin peluang bagi anak untuk dapat belajar dari pengalaman.

Sugiarto dan Andi Rahman dalam Webinar mengenai "Health Architecture \& Adapting Challenge Pasca Pandemi" menyebutkan bahwa penting untuk membuat rumah menjadi tempat nyaman saat harus melakukan Social Distancing agar terhindar dari stress dan kebosanan. Kuncinya ada di pencahayaan alami, ventilasi alami, dan penyediaan ruang terbuka hijau (Sugiarto \& Rahman, 2021) . 


\section{KESIMPULAN}

Dari hasil studi literatur yang dilakukan dapat disimpulkan bahwa untuk menyediakan ruang yang dapat membantu anak agar bisa mengikuti PJJ secara maksimal maka hal-hal yang dapat dilakukan adalah:

1) Pemberian bukaan untuk memasukkan cahaya dan pertukaran udara secara alami;

2) Peletakan ruang adaptatif yang dapat digunakan sebagai ruang belajar di tengah rumah atau di area yang memungkinan anak yang sedang menjalani PJJ untuk dapat sering berinteraksi dengan keluarga untuk mengurangi kemungkinan stress akibat tugas;

3) Memastikan anak dapat menyimak materi yang diberikan dengan jelas melalui perangkat yang dimiliki dengan cara mengatur arah orientasi belajar tidak membelakangi arah datangnya cahaya agar tidak terjadi glare yang membuat materi tidak terbaca;

4) Memiliki akses langsung ke ruang terbuka dalam rumah (misalnya taman) agar saat mulai merasa bosan anak dapat beristirahat sebentar dengan menghirup udara luar;

5) Penggunaan material yang beragam dan warna yang dapat membantu meningkatkan kemampuan otak saat belajar seperti warna biru dan kuning.

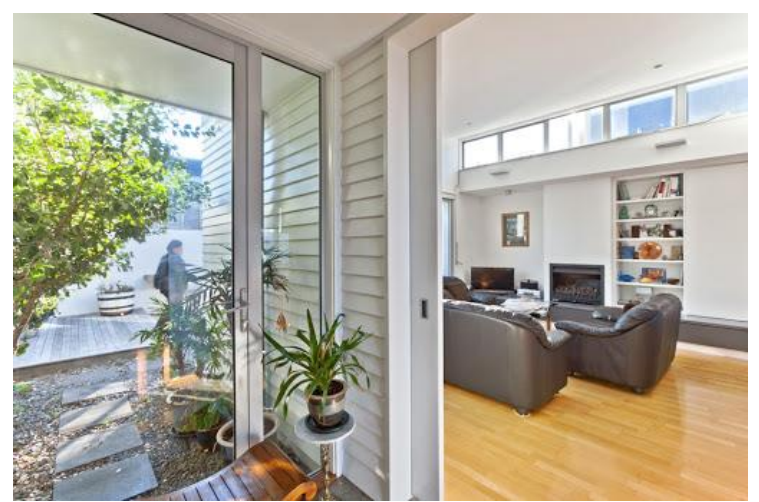

Gambar 8 Ilustrasi ruangan yang dapat digunakan sebagai ruang belajar adaptatif Sumber: Auckland Design Manual (https://bit.ly/3xlHcVx)

\section{SARAN}

Dengan segala kesulitan yang dihadapi di tengah pandemi Covid-19 ini ada banyak hal yang dapat kita jadikan pelajaran, salah satunya adalah perlunya kita menyiapkan diri terhadap munculnya wabah-wabah lain di masa depan. Tugas para arsiteklah untuk mencari tahu caracara untuk mengantisipasi dan merespon hal tersebut. Tujuan dari studi ini adalah untuk memberi masukan mengenai konsep ruang beajar yang adaptatif, selain sebagai pemicu agar studi-studi serupa lainnya dapat terus dilakukan agar di masa depan, jika terjadi sesuatu yang mengharuskan untuk tinggal di rumah dalam waktu lama, kita sudah memiliki dasar pengetahuan untuk meresponnya.

\section{DAFTAR PUSTAKA}

Ameliasari. (2019, November 11). Karakteristik Peserta Didik di Sekolah Dasar. Retrieved from Kompasiana: https://www.kompasiana.com/vinaameliasar i8163/5dc97b26097f360a56651102/karakter istik-peserta-didik-di-sekolah-dasar

Angdhiri, R. P. (2020, July 21). Lifestyle: Challenges of home learning during a pandemic through the eyes of a student. 
Retrieved from J+ By The Jakarta Post: https://www.thejakartapost.com/life/2020/04 /11/challenges-of-home-learning-during-apandemic-through-the-eyes-of-astudent.html

CDC. (2021, June 2). Ventilation in Building. Retrieved from CDC : Centers for Disease Control and Prevention: https://www.cdc.gov/coronavirus/2019ncov/community/ventilation.html

Harsono, F. H. (2020, Mei 13). Survei KPAI: Belajar di Rumah Selama COVID-19 Bikin Anak Stres dan Lelah. Retrieved from Liputan $6:$ https://www.liputan6.com/health/read/42516 22/survei-kpai-belajar-di-rumah-selamacovid-19-bikin-anak-stres-dan-lelah

KPAI. (2021, Februari 8). Infografis: Survei Pelaksanaan Pembelajaran Jarak Jauh (PJJ) dan Sistem Penilaian Jarak Jauh Berbasis Pengaduan KPAI. Retrieved from Bank Data KPAI: https://bankdata.kpai.go.id/infografis/surveipelaksanaan-pembelajaran-jarak-jauh-pjjdan-sistem-penilaian-jarak-jauh-berbasispengaduan-kpai

Lestari, S. (2018). Peran Teknologi Dalam Pendidikan di Era Globalisasi. Jurnal Pendidikan Agama Islam, 94-101.

McCabe, C. (2020, September 1). Health \& Wellness - Key to Preventing Covid-19 Indoors: Ventilation. Retrieved from The Wall Street Journal: https://www.wsj.com/articles/key-topreventing-covid-19-indoors-ventilation11598953607

Plump, A. (2021, May 18). First Opinion. Retrieved from STAT: https://www.statnews.com/2021/05/18/luckis-not-a-strategy-the-world-needs-to-startpreparing-now-for-the-next-pandemic/

Skorobogatov, G. (2016, February 16). Learning room. How does the room affect learning process? Retrieved from EPALE Electronic Platform for Adult Learning in Europe: https://epale.ec.europa.eu/en/blog/learningroom-how-does-room-affect-learningprocess- 0
Sugiarto, M., \& Rahman, A. (2021, June 12). Webinar Health Architecture \& Adapting Challenge Pasca Pandemi. Surakarta, Jawa Tengah, Indonesia.

Sugiyono. (2014). Metode Penelitian Kuantitatif Kualitatif dan $R \& D$. Bandung: Alfabeta. 